\title{
Botanics: a potential source of new therapies for Alzheimer's disease?
}

\author{
This article was published in the following Dove Press journal: \\ Botanics: Targets and Therapy \\ 3 April 2014 \\ Number of times this article has been viewed
}

\author{
Arif Nisha Syad \\ Kasi Pandima Devi \\ Department of Biotechnology, \\ Alagappa University, Karaikudi, \\ Tamil Nadu, India
}

Correspondence: Kasi Pandima Devi Department of Biotechnology, Alagappa University (Science Campus), Karaikudi 630 004, Tamil Nadu, India Tel +9l 4565225215

Fax +9l 4565225202

Email devikasi@yahoo.com

\begin{abstract}
Alzheimer's disease is an age-related, complex neurodegenerative disorder characterized by loss of memory and impairment of multiple cognitive functions. Several factors contribute to the progression and development of the disease including amyloid beta accumulation, neurofibrillary tangle formation, cholinergic deficit, oxidative stress, neuroinflammation, and apoptosis. Numerous traditional and herbal medicinal plants have been used to treat several cognitive disorders including Alzheimer's disease. They act as excellent antioxidants, anti-inflammatory mediators, and cholinesterase and $\beta$-secretase inhibitors. In addition, these natural compounds also prevent the accumulation of amyloid beta and its fibril formation. Besides acting as core-molecules, these natural compounds act as a template for the production and synthesis of several drug leads with improved pharmacokinetic potentials and greater efficacies. Hence, herbal medicines that have interesting pharmacological effects with noticeable anti-Alzheimer's potential deserve increased attention for further development to drug entities. The present article reviews the botanical pharmacology with special reference to anti-Alzheimer activity of plants and plant-derived compounds.
\end{abstract}

Keywords: neurodegeneration, medicinal plants, antioxidants, $\mathrm{A} \beta$ peptide, neuroprotective, clinical trials

\section{Introduction}

Alzheimer's disease (AD) is a progressive age-related neurodegenerative disorder characterized by progressive cognitive deficits and behavioral disturbances. Several complex pathogenic pathways have been found to be involved in the disease development and progression, including plaque formation, inflammatory cascade, cholinergic deficit, oxidative stress, etc. ${ }^{1}$ Formation of senile plaques and neurofibrillary tangles remain the most important neuropathological hallmarks of AD. Senile plaques are the major constituent of toxic amyloid beta $(A \beta)$ peptide, which is surrounded by dystrophic neurites and activated microglia. $A \beta$ accumulates as a result of altered proteolytic processing of amyloid precursor protein (APP) by $\beta$-secretase and $\gamma$-secretase. ${ }^{2}$ An increased amount of $A \beta$ (soluble monomeric form) self-aggregation into $\mathrm{A} \beta$ oligomers is found to be present in the brain of $\mathrm{AD}$ patients. These oligomers are highly toxic in nature and cause synaptic dysfunction due to oxidative stress and inflammation. ${ }^{3}$ It has been demonstrated that at least two intermediate processes are involved in the process of fibrillogenesis. ${ }^{4}$ The small oligomers undergo noncovalent interactions and form protofibrils, which are less structured than mature fibrils. The protofibrils, upon maturation, result in the formation of mature amyloid-like fibrils (Figure 1). ${ }^{4}$ 


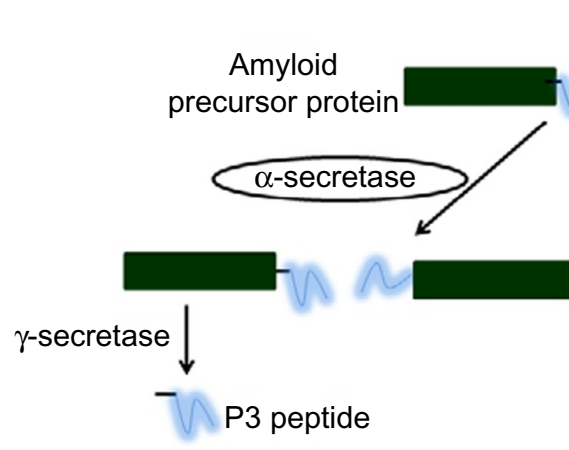

Non-amyloidogenic

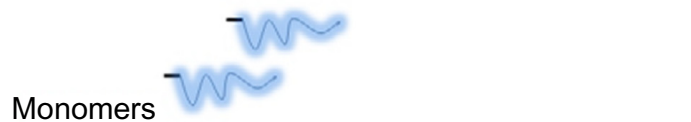

Monomers
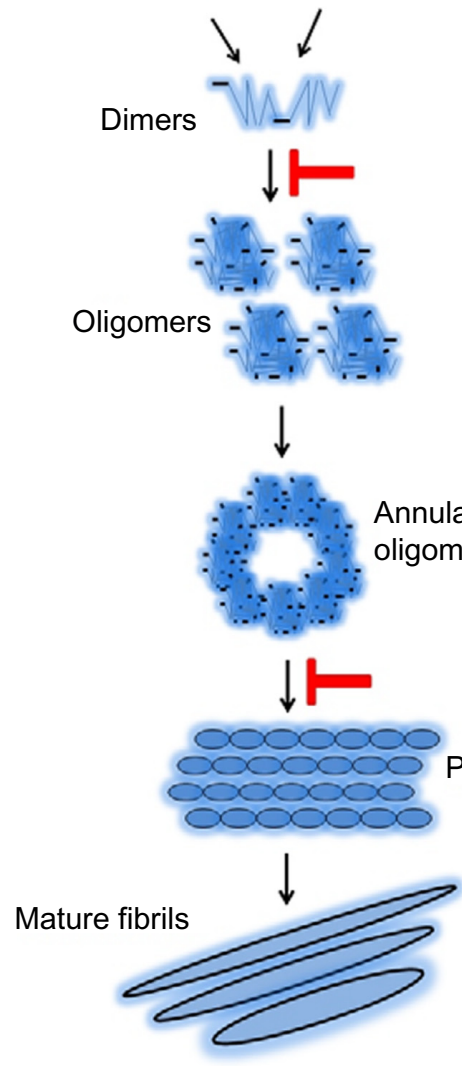

Protofibrils

\section{Inhibition by}

plant-derived compounds

Figure I Mechanism of generation of toxic $A \beta$ peptide and the fibril formation.

Note: Major targets for plant-derived natural compounds are indicated.

Abbreviation: $A \beta$, amyloid beta.

Apart from senile plaques, the presence of neurofibrillary tangles has been considered as another pathological event in AD. These neurofibrillary tangles are intracellular fibrillar aggregates of the microtubule-associated protein tau that exhibits hyperphosphorylation and oxidative modifications. ${ }^{2}$ Normally, the tau protein binds to microtubules and promotes the stability and assembly of microtubules. However, under diseased conditions, these tau proteins undergo hyperphosphorylation, which results in the decrease in affinity toward the microtubule and consequently causes aggregation. Recent evidence suggests that the level of hyperphosphorylated tau protein correlates with the degree of cognitive impairment in patients suffering from $\mathrm{AD} .^{3}$ 
Recent studies indicate that oxidative stress and free radical generation have been implicated as major etiological factors in the pathogenesis of AD. ${ }^{5-7}$ The free radicals generated in turn induce the formation of advanced glycation end products, nitration, lipid peroxidation adduction products, and also the carbonyl-modified neurofilament protein and free carbonyls, ultimately resulting in neuronal death (Figure 2). In addition to that, it has been verified that oxidative stress can induce amyloidogenic processing of beta-APP ( $\beta$-APP), resulting in accumulation of potentially neurotoxic $A \beta$ species. ${ }^{8}$

One of the earliest pathological events in $\mathrm{AD}$ is thought to be the dysfunction and loss of basal forebrain cholinergic neurons and their cortical projections. ${ }^{9}$ In general, two types of cholinesterases (ChEs) exist within the nervous system, acetylcholinesterase (AChE) that is primarily associated with cholinergic neurons and butyrylcholinesterase (BuChE), also known as pseudocholinesterase or nonspecific $\mathrm{ChE}$, a serine hydrolase that catalyses the hydrolysis of esters of choline that is associated with supporting glial cells and specific cholinergic nerve tracts. These ChEs are highly efficient since they are able to cleave more than 10,000 molecules of acetylcholine (ACh) per second and produce acetate and choline rapidly (Figure 2). ${ }^{10}$ Cholinergic neurons produce ACh (by the action of enzyme choline acetyl transferase), which gets concentrated in vesicles and released from the presynaptic cell following depolarization. Under diseased conditions, the activity of ChEs will be high, resulting in scarcity in the levels of $\mathrm{ACh}$, which ultimately results in the halt of neurotransmission. Furthermore, it has been previously demonstrated that $\mathrm{AChE}$ promotes $\mathrm{A} \beta$ aggregation and a remarkable increase in the cortical levels of $\mathrm{BuChE}$ has been found to be associated with neuritic plaques and neurofibrillary tangles, which are the major neuropathological features of $\mathrm{AD} .{ }^{11}$ Hence, in the current scenario, inhibitors of $\mathrm{AChE}$ and $\mathrm{BuChE}$ have become the major targets for the development of therapeutic strategies for AD. These $\mathrm{ChE}$ inhibitors enhance the cholinergic neurotransmission by prolonging the time in which ACh molecules remain in the synaptic cleft. ${ }^{12}$

Besides these factors, the role of metal ions in $A \beta$-mediated toxicity in AD-affected patients' brains has been largely implicated. Jomova et al ${ }^{13}$ suggest that an increase in the content of $\mathrm{Cu}$ and $\mathrm{Fe}$ in the brain results in the stimulation

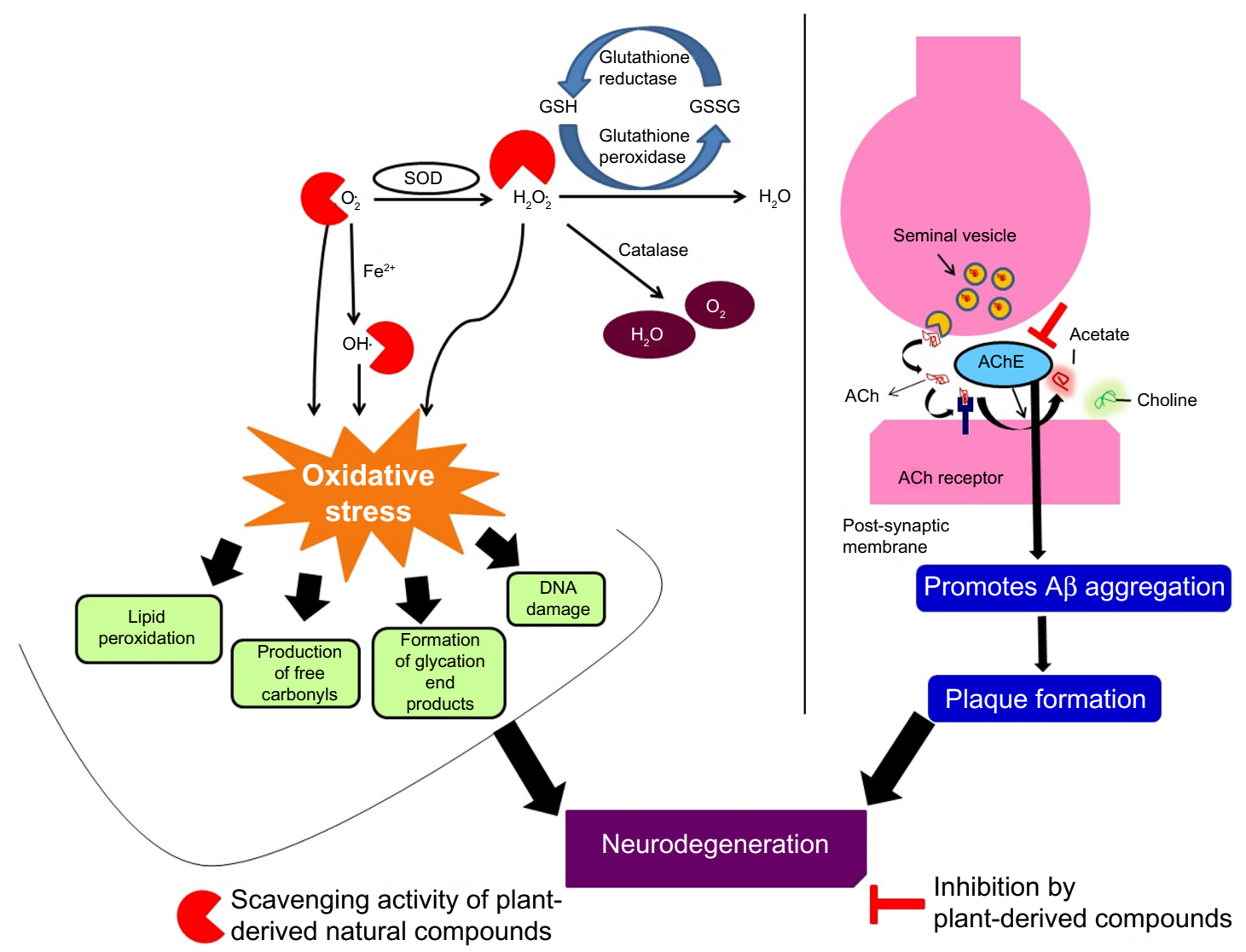

Figure 2 Role of oxidative stress and acetylcholinesterase in neurodegeneration.

Abbreviations: A $\beta$, amyloid beta; ACh, acetylcholine; AChE, acetylcholinesterase; GSH, glutathione; GSSG, glutathione disulfide; SOD, superoxide dismutase. 
of free radical generation, increased protein and DNA oxidation, and enhanced lipid peroxidation in AD. In addition, the aggregated state and structure of $A \beta$ peptide depends mainly on the concentration of peptide and the concentration of three metal ions like $\mathrm{Cu}, \mathrm{Zn}$, and $\mathrm{Fe}$. Interestingly, it has also been suggested that $\mathrm{Cu}(\mathrm{II}), \mathrm{Zn}(\mathrm{II})$, and $\mathrm{Fe}(\mathrm{III})$ binds to $\mathrm{A} \beta$ with high affinity and the levels of these metal ions were found to be in higher amounts in the neocortex region, where the amyloid plaques are present to a great extent.

The involvement of the inflammatory process has been greatly implicated in the pathogenesis of AD. ${ }^{14-16}$ Although the inflammatory reaction has been believed to be the first line of protection against injury, abnormal increase in the activation of inflammatory players contributes to the deleterious neurodegenerative processes. The neuroinflammatory process involves activated microglial cells, astrocytes, neurons, and complement systems. The formation of senile plaques in AD also involves the chronic activation and dysfunction of microglial cells. In addition, high levels of interleukin (IL)-1 are often found in the proximity of $A \beta$ plaques and neurofibrillary tangles. ${ }^{17}$ It has also been verified that the production of IL-6 by microglial cells directs the effective clearance of A $\beta$, which suggests that normal microglial cells are excellent in clearing $A \beta$; however, it fails in its function whenever there is a rapid accumulation of a large amount of $A \beta$ peptides. ${ }^{18}$ Earlier findings suggest that apoptotic cell death is a common feature shared by sporadic and familial forms of AD. ${ }^{2,19}$ The presence of fragmented DNA, activated forms of caspases (3, 8, and 9), and altered expression of cell-death-related genes like $\mathrm{Bcl}$-2 suggests that apoptosis might be one of the central mechanisms leading to neuronal death in AD. Moreover, A $\beta$ has been considered as the trigger of apoptotic cell death, as pro-apoptotic proteins were found to be associated with $\mathrm{A} \beta$ deposits in the brains of $\mathrm{AD}$ patients. ${ }^{20}$ In addition, $\mathrm{A} \beta$ activates the mitochondrial cell death pathway indirectly by promoting oxidative stress through the production of reactive oxygen species (ROS; prime pro-apoptotic molecules) and it was also found to induce the death-receptor pathway by interacting with the cell membrane receptors present in microglia including tumor necrosis factor alpha (TNF- $\alpha$ ) receptor, $\mathrm{p} 75$ receptors, and receptors for advanced glycation endproducts, which promotes neuronal apoptosis. ${ }^{21}$

In addition to the abovementioned factors, neurovascular dysfunction also contributes to cognitive deficit and neurodegeneration in AD. The neurovascular system in the brain controls the internal environment of neurons by regulating local cerebral blood flow and transport across the blood-brain barrier (BBB). ${ }^{22}$ Notable changes like reduced microvascu- lar density, increase in the number of fragmented vesicles, irregular capillary surfaces, and collagen accumulation in the basement membrane have been observed in the brains of AD patients, suggesting a strong association between cerebrovascular disorder and AD. ${ }^{23,24}$ Transport across the $\mathrm{BBB}$ is highly influenced by the concentration of soluble $\mathrm{A} \beta$ in central nervous system. ${ }^{25}$ Under physiological conditions, the amount of free $A \beta$ in brain interstitial fluid is higher than the in plasma. Increased basal level $A \beta$ in plasma than the body fluids and interstitial fluids has also been reported in AD mice. ${ }^{26}$ It has long been known that apolipoprotein $\mathrm{E}$ (APOE4) is involved in the binding and metabolism of lipids, and in the clearance of $A \beta$ from the brain. ${ }^{27} \mathrm{~A}$ protein variant APOE4 of mice induces a destructive inflammatory response in pericytes (cells that wrap around blood vessels and seal off the BBB). The resulting breach in the barrier results in the leakage of molecules that are toxic to neurons and cause abnormal changes in the brain. Therefore, researchers have started targeting these inflamed pericytes and other vascular abnormalities that cause neurodegeneration. ${ }^{28}$

\section{Botanical pharmacology}

For several decades natural products have been used as traditional medicine to treat several diseases and disorders. Most of these traditional herbal medicines are complex mixtures of chemical components possessing diverse biological and pharmacological activities. Theoretically, these medicines have been believed to maintain the level of vital energy in our body. In recent years, the effort to develop drugs from natural sources has increased tremendously, which has resulted in the development of a wide range of natural-productderived drugs against a large number debilitating diseases. Interestingly, noticeable effort has been made to develop potential anti-AD agents from natural products..$^{29,30}$

\section{Botanics as source of drugs}

Houghton $^{31}$ suggests that many important drugs employed in modern medicines consist of active principles derived from traditional medicines, which have been used as the only drug of choice for particular conditions. The use of the Digitalis species-derived compound, digoxin (cardiotonic glycoside) and analgesic-activity-bearing compounds such as morphine and codeine from opium poppy, Papaver somniferum L. (Papaveraceae), have a long history of use. There are certain medicinal plant-derived compounds which cannot be used in their native forms, and hence are chemically modified to attain the best therapeutic potentials. One fine example is the antimalarial compound artemesinin, derived from the 
Chinese medicinal herb Artemisia annua L. (Asteraceae). Artemesinin, by nature, is insoluble in water; hence, it poses problems during administration, whereas sodium artesunate, a derivative of artemesinin that was developed, has good solubility in water without losing its antimalarial potency. Another compound, lignocaine (derived from cocaine), was designed by removing its addictive properties and retaining the features of cocaine that are vital for its anesthetic activity. Hence, the natural compounds, apart from exhibiting excellent therapeutic values directly, also serve as lead compounds for the development of novel compounds with improved activities and reduced side effects.

\section{Mode of action of medicinal plants against $A D$}

One of the standard anti-AD drugs, galantamine (alkaloid), was isolated from bulbs and flowers of Galanthus woronowi Losinsk. (Amaryllidaceae). The mode of action of this Food and Drug Administration (FDA)-approved drug is inhibition of AChE.$^{32}$ In addition, terpenoids like ginsenosides obtained from Panax ginseng L. (Araliaceae) have been studied extensively on their anti-AD efficacy. ${ }^{3}$ The mode of action of a wide range of medicinal plants which are being screened to lessen the effects of several pathological consequences of $\mathrm{AD}$ are discussed below.

\section{Plants as a source of antioxidants}

Oxidative stress plays a central role in AD pathogenesis, in which several factors are reported to influence the rapid generation of ROS in the AD brain. The brain is more vulnerable to oxidative stress since it requires a high amount of oxygen per unit of weight. Moreover, the brain region is rich in oxidizable polyunsaturated fatty acids, which are highly susceptible to lipid peroxidation. In addition, mitochondrial dysfunction with age also contributes to increased production of ROS in the AD brain. The major source of production of ROS by mitochondria in aged persons is identified as electron transport complexes I and III. ${ }^{33}$ An Increase in the concentration of iron causes ROS generation, which further promotes protein modifications and subsequent damage. A sudden increase in activated microglial cells also represents a major source of ROS. ${ }^{34}$

Over the past several years, natural antioxidants such as polyphenols have been considered as an alternative for the treatment of age-related neurological disorders. ${ }^{35,36}$ Polyphenols are plant-derived secondary metabolites, which represent a broad group of compounds having aromatic rings and are characterized by the presence of hydroxyl groups with varied structural complexities. These polyphenols execute neuroprotective effects through a variety of actions like inactivation of free radicals, interaction with transition metals, and modulating the activities of antioxidant enzymes. ${ }^{37}$ The methanol-water $(8: 2)$ extract of leaves of Ricinus communis L. (Euphorbiaceae) has been found to exhibit significant antioxidant activity and the presence of Gallic acid, quercetin, gentisic acid, rutin, epicatechin, and ellagic acid has been attributed to the observed activity. ${ }^{29}$ Orhan and Aslan $^{38}$ demonstrated that Salvia triloba L., Teucrium polium L., and Melissa officinalis L. showed strong radical scavenging activity against 2, 2-diphenyl-1-picrylhydrazyl radicals. In addition, extensive studies have been carried out to delineate the antioxidant potential of several medicinal plants. $^{39-44}$

\section{ChE inhibitors}

One of the neurochemical alterations that occur in $\mathrm{AD}$ is the cholinergic deficit, which is caused either due to the reduced production of $\mathrm{ACh}$ or due to the abnormal increase in the activity of the enzyme AChE. Hence, ChE inhibitors are considered as the standard drugs for the treatment of AD. Tacrine (1, 2, 3, 4-tetrahydro-9-aminoacridine) was the first drug, which was approved as a ChE inhibitor for the treatment of AD. ${ }^{45}$ Later, various AChE inhibitors were developed including donepezil, galantamine, rivastigmine, etc. ${ }^{46}$ In recent years, a large variety of plants and their crude extracts have been screened for anti-ChE activity, which are listed in Table 1.

\section{Anti-amyloidogenic activities of medicinal plants}

One of the key pathological effects in AD is fibrillation of $\mathrm{A} \beta$ peptide and the formation of toxic oligomers. Hence, preventing the aggregation of the $A \beta$ peptide might help in the treatment of AD. Several medicinal plants have been found to exhibit anti-amyloidogenic activities. In particular, they exhibit specific effects on the formation of aggregates and destabilization of preformed fibrillar structures in brain. Since the formation of fibrillar aggregates remains the most important pathological event, the plants with potential antiamyloidogenic activity will be highly beneficial in developing novel drug leads against AD.

Fujiwara et $\mathrm{a}^{69}$ demonstrated that Uncaria rhynchophylla Miq. (Rubiaceae), a traditional Chinese medicinal herb, exhibits excellent inhibitory activity against aggregation of both $A \beta$ 1-40 and $A \beta$ 1-42 peptide and also on the assembly of A $\beta$ fibrils. Another Chinese traditional herbal medicine, Paeonia suffruticosa Andrews (Paeoniaceae) (methanolic, 
Table I Plants with potential AChE inhibitory activity

\begin{tabular}{|c|c|c|c|c|}
\hline Serial number & Plant & Family & Extract/active compound & References \\
\hline I & Angelica archangelica $\mathrm{L}$. & Apiaceae & Unknown & Howes et $\mathrm{al}^{46}$ \\
\hline 2 & Coptis Chinensis Franch & Ranunculaceae & Berberine, palmatine & Howes et $\mathrm{a}^{46}$ \\
\hline 3 & Evodia rutaecarpa (Juss.) & Tetradium & Dehydroevodiamine & Howes et $\mathrm{al}^{46}$ \\
\hline 4 & Polygala tenuifoila Willd. & Polygalaceae & Root extract & Howes et $\mathrm{a}^{46}$ \\
\hline 5 & Salvia officinalis $\mathrm{L}$. & Labiatae & Ethanolic extract & Howes et $\mathrm{al}^{46}$ \\
\hline 6 & Salvia lavandulaefolia Vahl. & Labiatae & I,8-cineole and $\alpha$-pinene & Howes et $\mathrm{al}^{46}$ \\
\hline 7 & Withania somnifera (L.) Dunal & Solanaceae & Sitoindosides & Howes et $\mathrm{al}^{46}$ \\
\hline 8 & Andrographis paniculata Nees & Acanthaceae & Hydroalcohol extract & Mukherjee et $\mathrm{a}^{47}$ \\
\hline 9 & $\begin{array}{l}\text { Nardostachys jatamansi } \\
\text { (D. Don) DC. }\end{array}$ & Valerianaceae & Hydroalcohol extract & Mukherjee et $\mathrm{al}^{47}$ \\
\hline 10 & Nelumbo nucifera Gaertn & Nymphaeaceae & Hydroalcohol extract & Mukherjee et $\mathrm{a}^{47}$ \\
\hline II & Myristica fragrans Houtt & Myristicaceae & Hydroalcohol extract & Mukherjee et $\mathrm{a}^{47}$ \\
\hline 12 & Evalvulus alsinoides L. & Convolvulaceae & Hydroalcohol extract & Mukherjee et $\mathrm{al}^{47}$ \\
\hline 13 & Scoparia dulcis $\mathrm{L}$. & Scrophulariaceae & Chloroform extract & Coulibaly et a $\left.\right|^{48}$ \\
\hline 14 & Centella asiatica (L.) Urban & Umbelliferae & $\alpha$-pinene, $\beta$-pinene, $\gamma$-terpinene & Miyazawa et al ${ }^{49}$ \\
\hline 14 & Bacopa monniera Wettst. & Plantaginaceae & Ethanolic extract & Ahirwar et $a^{50}$ \\
\hline 15 & Lippia stoechadifolia H. B. & Verbenaceae & Pulegone-I, 2-epoxide & Grundy and Still ${ }^{51}$ \\
\hline 16 & $\begin{array}{l}\text { Magnolia officinalis Rehder \& } \\
\text { Wilson }\end{array}$ & Magnoliaceae & Honokiol & Hou et $\mathrm{al}^{52}$ \\
\hline 17 & Melissa officinalis L. & Lamiaceae & Essential oil fraction & Ferreira et $\mathrm{al}^{53}$ \\
\hline 18 & Huperzia serrata Brehn. & Lycopodiaceae & Huperzine A & Wang et $\mathrm{al}^{54}$ \\
\hline 19 & Salvia miltiorrhiza Bunge. & Lamiaceaea & Dihydrotanshinone, cryptotanshinone & Ren et $\mathrm{al}^{55}$ \\
\hline 20 & Desmodium pulchellum (L.) Benth & Papilionaceae & $\beta$-carbolines & Ghosal et $\mathrm{a}^{56}$ \\
\hline 21 & Prosopis juliflora (Sw.) DC & Papilionaceae & Juliflorine & Choudhary et al ${ }^{57}$ \\
\hline 22 & Sarcococca saligna (D. Don) & Buxaceae & $\begin{array}{l}\text { Salignenamides-C, -E and -F, axillarine- } \\
\text { C, saligcinnamide, vaganine-A, } \\
\text { 5,6-dehydrosarconidine, } \\
\text { 2-hydroxysalignarine-E, salignamine, } \\
\text { 2-hydroxysalignamine-E, epipachysamine-D, } \\
\text { dictyophlebine, iso- } \mathrm{N} \text { - } \\
\text { formylchonemorphine and axillaridine-A }\end{array}$ & Khalid et $\mathrm{al}^{58}$ \\
\hline 23 & Narcissus pseudonarcissus L. & Amaryllidaceae & Lycorine & Acqua $^{59}$ \\
\hline 24 & $\begin{array}{l}\text { Cocculus pendulus (J. R. and G. } \\
\text { Frost.) Diels }\end{array}$ & Menispermaceae & $\begin{array}{l}\text { kurramine- } 2^{\prime}-\beta-N \text {-oxide and kurramine- } \\
2^{\prime}-\alpha-N \text {-oxide }\end{array}$ & Atta-Ur-Rahman ${ }^{60}$ \\
\hline 25 & Otostegia limbata (Benth.) & Lamiaceae & cis-clerodane & Ahmad et $\mathrm{a}^{61}$ \\
\hline 26 & Cynanchum atratum Bunge. & Asclepiadaceae & Cynatroside B & Lee et $\mathrm{al}^{62}$ \\
\hline 27 & Buxus papillosa C.K. Schneider & Buxaceae & Buxamines $B$ and $C$ & Khalid et $\mathrm{al}^{63}$ \\
\hline 28 & $\begin{array}{l}\text { Tabernaemontana australis } \\
\text { (Müell. Arg) }\end{array}$ & Apocynaceae & $\begin{array}{l}\text { Coronaridine, voacangine, voacangine } \\
\text { hydroxyindolenine and rupicoline }\end{array}$ & Andrade et $\mathrm{al}^{64}$ \\
\hline 29 & Evodia rutaecarpa Juss. & Rutaceae & Dehydroevodiamine & Park et al ${ }^{65}$ \\
\hline 30 & Origanum majorana $\mathrm{L}$. & Lamiaceae & Ursolic acid & Chung et $\mathrm{al}^{66}$ \\
\hline 31 & Lycopodium clavatum L. & Lycopodiaceae & $\alpha$-onocerin & Orhan et $\mathrm{a}^{67}$ \\
\hline 32 & Citrus junos Siebold ex. Tanaka & Rutaceae & Naringenin & Heo et $a^{68}$ \\
\hline
\end{tabular}

Abbreviation: AChE, acetylcholinesterase.

ethanolic and water extracts) showed inhibitory effect on $A \beta$ fibril formation and also promoted defibrillation of preformed $A \beta$ fibrils in a concentration dependent manner. In addition to that, it has been revealed that the inhibition exhibited by . suffruticosa is independent on the presence of distinct amino acids present in the C-terminal region, as it displayed its inhibitory activity against both $A \beta \quad 1-40$ and A $\beta$ 1-42. ${ }^{70}$ Papandreou et $\mathrm{al}^{71}$ studied the anti-aggregation potential of Crocus sativus L. (Iridaceae) stigmas extract and the results suggest that the extract significantly inhibited the formation of amyloid fibrils in a concentration- and timedependent manner. Salvianolic acid B, derived from Salvia miltiorrhiza Bunge. (Lamiaceae) and a Chinese herbal medicine commonly used for the treatment of cardiovascular and cerebrovascular disorders, has been evaluated for its effect on A $\beta$ fibrillation and disaggregation of fibrils. The outcome of the study suggests that salvianolic acid B inhibits fibril aggregation and destabilizes the $A \beta$ fibril, dose-dependently. ${ }^{72}$ 
Another study led by Kang et $\mathrm{al}^{73}$ verified that the butanolic extract of Ecklonia cava Kjellman (Lessoniaceae) reduces the production of toxic A $\beta$ peptide from APP with Swedish mutation. The results of the study also suggest that the extract inhibited the formation of mid-size oligomers from the soluble monomers. More interestingly, the extract has been found to inhibit fibril formation from insoluble oligomers, which suggests that the butanolic extract of E. cava ameliorates $\mathrm{A} \beta$-mediated neuronal death. Curcumin (diferuloylmethane), a low molecular weight compound, has been found to exhibit brilliant antioxidant and anti-inflammatory activities when checked with various in vivo and in vitro model systems. Yang et $\mathrm{al}^{74}$ evaluated the effect of curcumin on the aggregation and disaggregation of $\mathrm{A} \beta$ peptide using in vitro and in vivo systems. The results of the study revealed that curcumin directly binds to small $\mathrm{A} \beta$ peptide to block aggregation and fibril formation. In addition, curcumin, when given in a low dose, promotes the disaggregation of preformed fibrils. Apart from the abovementioned herbal medicines, several edible food constituents have also been verified for their antiamyloidogenic activities including ellagic acid, garlic acid, and mulberry leaf extract. The results of the study suggest that they induce anti-aggregation and defibrillation activities when checked in various model systems. ${ }^{75-77}$

\section{Anti-inflammatory activities of medicinal plants}

Although $A \beta$ accumulation and aggregation of hyperphosphorylated tau in different neuronal compartments are reported to be associated with neuronal loss and synaptic dysfunction in $\mathrm{AD}$, the impact of neuroinflammation has also been implicated in the pathogenesis of $\mathrm{AD}^{78}$ In addition, accumulation of activated microglial cells (the predominant macrophage species within the brain) has been correlated with decline in cognition in $\mathrm{AD} .^{79} \mathrm{~A} \beta$ induces the execution of the inflammatory process through enhanced cytokine production and increased release of TNF- $\alpha$ and IL-1 $\beta$. In addition, the induction of such an inflammatory response has been apparently observed in the brains of AD patients. ${ }^{79}$ Several studies have shown that the use of nonsteroidal anti-inflammatory drugs (NSAIDs) may reduce the risk of developing $\mathrm{AD}$, and that patients with rheumatoid arthritis, who often use NSAIDs, have a lower incidence of developing AD. ${ }^{80-85}$ However, prolonged usage of chemical NSAIDs can cause damage to several organs. Hence, targeting the inflammation cascade with natural products might act as a potent therapeutic option for AD.

Recent researchers have started focusing on herbal medicines to verify the presence of anti-inflammatory activity compounds in them. Dipsacus asper Wall (Dipsacaceae) is a perennial herb, which was used traditionally in China for the treatment of rheumatic arthritis, traumatic hematoma, and bone fractures, and to threaten abortion. Akebia Saponin D (ASD), a typical bioactive triterpenoid saponin isolated from the rhizome of $D$. asper, was assessed for its antiinflammatory effect on $A \beta$ 1-42 administered rat animal models. The results suggest that ASD inhibited the expression of TNF- $\alpha$, IL- $1 \beta$, and cyclooxygenase 2 (COX-2) in rat brain. In addition, the saponin also inhibited Akt and nuclear factor kappa-light-chain-enhancer of activated B cells, suggesting that ASD possesses potential anti-inflammatory activity ${ }^{86}$ Ginger extract isolated from Zingiber officinale inhibited lipopolysaccharides (LPS), cytokine, and amyloid $\mathrm{A} \beta$-peptide-induced expression of the proinflammatory genes TNF- $\alpha, I L-1 \beta, C O X-2$, macrophage inflammatory protein alpha, monocyte chemotactic protein-1, and interferon gamma-induced protein 10 . The study gives experimental evidence that ginger can inhibit the activation of human monocytic THP-1 cells by different proinflammatory stimuli and reduce the expression of a wide range of inflammationrelated genes in the microglial-like cells studied. ${ }^{87}$

The defective clearance of $A \beta$ peptide by the innate immune system is related to the brain amyloidosis in patients with AD. Certain phenolic compounds, like curcuminoids, downregulate the expression of inflammatory enzymes apart from increasing the phagocytosis of $A \beta$ peptide in macrophages of nearly $50 \%$ of AD patients. ${ }^{88} \mathrm{In}$ THP-1 monocytic cells, curcumin isolated from Curcuma longa inhibited $\mathrm{A} \beta$-induced expression of Egr-1 protein and Egr-1 DNA-binding activity. Egr-1 has been shown to have a role in amyloid-peptide-induced cytochemokine gene expression in monocytes. Hence, curcumin can reduce inflammation in monocytes through inhibition of Erg-1 and further the chemotaxis of monocytes, which can occur in response to chemokines from activated microglia and astrocytes in the brain..$^{89,90}$

Numerous other medicinal plants have been screened for anti-inflammatory activities. The anti-inflammatory activity of Kalanchoe pinnata (Lam.) Pers. (Crassulaceae) and Sarcostemma secamone L. Bennet (Asclepiadaceae) was evaluated using carrageenan-induced paw-edema-bearing rats. The results showed that the ethanolic extract of both medicinal plants exhibited a significant anti-inflammatory activity in paw-edema-bearing rats..$^{91,92}$ Leal et al ${ }^{93}$ assessed the anti-inflammatory activities of five traditionally used Brazilian medicinal plants, including Torresea cearensis Allemão (Fabaceae), Justicia pectoralis Jacq. (Acanthaceae), 
Eclipta alba L. (Asteraceae), Pterodon polygaliflorus Benth. (Pteranodontidae), and Hybanthus ipecacuanha L. Baill (Violaceae Batsch). Among them, the hydroalcoholic extract of $T$. cearensis alone showed excellent anti-inflammatory activity in carrageenan-induced paw-edema-bearing rats. Other plant extracts exhibit anti-inflammatory activity intraperitoneally. A similar study was carried out to validate the anti-inflammatory activity of 14 Chinese medicinal plants by measuring the inhibition of the production of nitric oxide and TNF- $\alpha$ in LPS- and interferon-gamma-activated RAW 264.7 macrophages. The outcome of the study suggested that out of 14 plants, only five plant extracts showed significant anti-inflammatory activity, which includes the plant extracts of Scutellaria baicalensis Georgi (Lamiaceae), Taxillus chinensis Danser (Loranthaceae), Sophora japonica L. Schott (Fabaceae), Mahonia fortunei (Lindl.) Fedde (Berberidaceae), and Sophora flavescens Aiton (Fabaceae) ${ }^{94}$ Sharififar et al ${ }^{95}$ studied the anti-inflammatory effect of four Iranian medicinal plants Trigonella foenumgraecum L. (Fabaceae), Zhumeria majdae Rech. (Nepetoidae), Achillea wilhelsii C. Koch (Asteraceae), and Viola tricolor L. (Violaceae).

Screening of these anti-inflammatory plants further against $A \beta$-induced inflammatory reaction could help in the identification of new agents for preventing $A \beta$-peptideinduced inflammation in AD.

\section{Plants as $\beta$-secretase inhibitors}

$\beta$-site APP cleaving enzyme 1 (BACE-1), also known as $\beta$-secretase 1 , a transmembrane aspartic protease is secreted in all tissues, but is present in higher amount in neurons of the brain. It is the key enzyme which cleaves the APP to form $\mathrm{N}$-terminus of $\mathrm{A} \beta$ peptide followed by $\gamma$-secretase, which cleaves the C-99 fragment to generate C-terminus of $A \beta$ and the mature peptide (Figure 1). ${ }^{96}$ Compared to $\gamma$-secretase, $\beta$-secretase has become the most promising target for pharmaceutical research on $\mathrm{AD}$ therapeutics since $\gamma$-secretase has a potential side effect of inhibiting another important target, the Notch protein. Thus if $\gamma$-secretase is inhibited, neuronal development will be affected as Notch has multiple other substrates and also serves important functions in neuronal development. ${ }^{97}$

Several plant extracts and plant-derived compounds have been found to have influence on the pathways of $A \beta$ production, in particular by interacting with brain enzymes like $\beta$ - and $\gamma$-secretases. ${ }^{98}$ Kwak et al ${ }^{96}$ identified the presence of two $\beta$-secretase inhibitors (ellagic acid and punicalagin) from the husk of pomegranate, Punica granatum L. (Lythraceae).
Both of these compounds were found to be more specific in inhibiting $\beta$-secretase as they exhibited lesser inhibitory effect against $\alpha$-secretase activity. Another study led by Hwang et $\mathrm{a}^{99}$ showed that the lipophilic alkylated flavanones from $S$. flavescens Aiton. (Fabaceae) possess an excellent BACE-1 inhibiting effect, verified by using transfected human embryonic kidney (HEK-293) cells. The mode of inhibition exhibited by the flavonones was a noncompetitive type. Recent research on the dried rhizomes of Smilax china L. (Smilacaceae) suggests that the ethyl acetate soluble fraction of the rhizome possesses potent inhibitory activity against BACE-1. The active components identified from the fractions were trans/cis-resveratrol mixture, oxyresveratrol, veraphenol, and cis-scirpusin A. ${ }^{100}$ It has also been demonstrated that green and black tea polyphenols exhibit potential BACE-1 inhibitory activity, thereby reducing the progression of AD. ${ }^{101,102}$

Even with BACE-1 inhibition, the major concern is the inhibition of non-APP substrates like P-selectin glycoprotein ligand-1 or low-density lipoprotein receptor-related protein. Hence, drugs which bind to APP rather than BACE-1, known as APP selective BACE inhibitors (ASBI) are desired. An attempt was made by Descamps et a ${ }^{17}$ to screen nearly 448 clinical compounds in an ASBI assay (a high throughput assay developed for screening for BACE inhibitors), in which the bioflavonoid rutin (a citrus flavonoid glycoside) and galangin (a bioflavonoid from the galangal rhizome) were identified as potent ASBIs. Before these drugs are taken up for clinical trial as ASBIs, further research on pharmacokinetics and improving their potency is required.

\section{Protective effect of natural compounds against BBB breakdown}

Cerebrovascular lesion has been found to impart major effects in $\mathrm{AD}$. In addition, $\mathrm{A} \beta$ protein degenerates the larger perforating arterial vessels and cerebral capillaries of the BBB. ${ }^{103}$ As the alteration in BBB profoundly contributes to $\mathrm{AD}$ pathology, researchers have started focusing on the development of compounds from natural sources that combat these abnormalities. Curcumin, a phenolic compound from the rhizome of C. longa Linn. (Zingiberaceae), has been reported to protect the BBB integrity. ${ }^{104}$ Several reports have also demonstrated that flavonoids affords protection to endothelial cells against ROS and inflammatory insults mediated BBB breakdown and related neuronal dysfunction. ${ }^{105-108}$

It has been verified that brain endothelial cells play a crucial role as structural and functional components of the BBB. 
Abnormal increases in the BBB disruption are associated with neuroinflammation and, in turn, trigger the expression of matrix metalloproteinase expression. ${ }^{109}$ In view of this, Tahanian et $\mathrm{al}^{110}$ verified the protective effect of non-glycosidic flavonoids against major inflammatory markers like matrix metalloproteinase 9 and COX-2 proteins. Flavonoids like fisetin, apigenin, and luteolin were found to inhibit inflammatory biomarkers like matrix metalloproteinase 9 and COX-2 expression in a dose-dependent manner.

\section{Plants as $\gamma$-secretase inhibitors}

$\gamma$ - secretase is the enzyme that cleaves $\beta$-APP in the transmembrane domain and generates the toxic $A \beta$ peptides. In addition to the $\beta$-APP processing, $\gamma$-secretase plays a crucial role in the cleavage of the Notch family of cell surface receptors, a protein required for the transcriptional regulation during development. ${ }^{11}$ Therefore, the use of $\gamma$-secretase inhibitors has provided insights into proteolytic activity and suggests that such inhibition might be a useful therapeutic strategy. ${ }^{112}$ Lee et al ${ }^{113}$ demonstrated that the green tea polyphenol epigallocatechin-3-gallate inhibited LPS-induced elevation of A $\beta$ levels through the attenuation of LPS-induced $\beta$ - and $\gamma$-secretase activities. A novel triterpene isolated from the extract of Actaea racemosa reduces $\mathrm{A} \beta$-induced toxicity through the modulation of $\gamma$-secretase activity. It has also been suggested that the compound may bind to the $\gamma$-secretase complex or the $\gamma$-secretase-APP complex, modulating the cleavage of APP and thereby reducing the formation of $A \beta$ peptides. ${ }^{114}$

\section{Pharmacokinetic properties of the natural products targeted against $A D$}

$\mathrm{AD}$ is a complex neurodegenerative disorder, which is characterized by several pathological hallmarks including oxidative stress, increase in AChE activity, mitochondrial dysfunction, neuroinflammation, etc. Due to this complex molecular pathogenicity, many of the effective therapeutic strategies for $\mathrm{AD}$ remain ineffective in treating the disorder. Henceforth, a compound that is able to interact with multiple molecular targets involved in the neurodegeneration cascade might be more successful to treat AD efficiently. The advent of defined high-throughput screening assays facilitates the consistent profiling of large number of compounds against a panel of targets and the verification of the multifunctional nature of existing natural compounds and drug leads. However, this can be achieved only by the rapid screening of pharmacologically active compounds against their prospective targets using a pharmacokinetics approach. ${ }^{115}$
One of the major problems in studying the complex mixtures found in botanicals is measuring the absorption, distribution, and elimination of different components. Certain secondary metabolites with potential bioactivity would not be found in the presumed target tissue, which will end up in a poor understanding of the drug action. Therefore, pharmacokinetic studies facilitate a better understanding of the drug action, including its positive and negative effects. ${ }^{116}$ Pharmacokinetics involves the study of the fate of a drug administered externally to an organism. It attempts to evaluate the fate of a drug from the moment that it is administered up to the point at which it is completely eliminated from the body. Pharmacokinetics describes how the body affects a specific drug after administration through the mechanisms of absorption and distribution and the chemical changes of the substance in the body and the effects and routes of excretion of the metabolites of the drug. One such study was undertaken to determine the kinetics and tissue distribution of different grape polyphenolic fractions using the ${ }^{14} \mathrm{C}$ labelling technique. By this method, ${ }^{14} \mathrm{C}$-labelled grape polyphenols were produced in tissue culture and fractionated into 23 fractions and administered orally to rats. The polyphenols were tracked using several advanced techniques like mass spectrometry, microdialysis, and conventional liquid scintillation counting techniques. ${ }^{116}$ Since natural compounds remain a promising source for drug development against $A D$, several researchers have started focusing on pharmacokinetic properties for an in-depth understanding of the fate of the drug inside living systems.

The pharmacodynamic profile of the drug galantamine (a recently approved $\mathrm{ChE}$ inhibitor), suggests that it has a clinically significant dual mechanism of action, which is the reversible competitive inhibition of AChE and allosteric modulation of the nicotinic receptor. ${ }^{117}$ In general, the nicotinic receptor plays a vital role in cognition, as it controls the release of several neurotransmitters from the presynaptic terminal. ${ }^{118}$ Galantamine appears to bind to an allosteric site on the nicotinic receptor, causing a conformational change, resulting in an increased release of ACh, which increases the cholinergic functions. ${ }^{119}$ On the other hand, galantamine inhibits AChE reversible inhibition, thereby increasing the availability of $\mathrm{ACh}$ in the brain. The pharmacokinetic profile describes that galantamine gets absorbed and extensively distributed throughout the tissues of the body. Galantamine is metabolized rapidly by cytochrome P450 isoenzymes and no single elimination pathway seems to be predominant, as multiple metabolic pathways are involved. ${ }^{117}$ 
Huperzine A, another potent and more specific AChE inhibitor, which crosses the BBB smoothly, has been approved as a drug for treatment of $\mathrm{AD}$ in China. It induces significant improvement in the memory of elderly people with $\mathrm{AD}$ and vascular dementia. Although huperzine $\mathrm{A}$ is currently in clinical trials, very little information is available on its pharmacokinetics and pharmacodynamics profiles. Pharmacokinetic studies on huperzine A reveal that it exhibits a rapid and nearly complete oral absorption and that the relative bioavailability was moderate. ${ }^{120}$ Physostigmine (the oldest known ChE inhibitor) inhibits both $\mathrm{AChE}$ and $\mathrm{BuChE}$ by acting as a pseudosubstrate and transferring a carbamate residue to the active site of the enzyme. It is a tertiary amine, which is lipid soluble with a pKa value of 7.9 and around $75 \%$ of the drug gets ionized at the $\mathrm{pH}$ of blood and brain. Pharmacokinetic studies show that physostigmine is eliminated completely through the metabolic pathways. Following intravenous administration, the distribution pattern in the brain was analyzed and the results showed that physostigmine deposition was highest in the striatum, moderate in the cortex and hippocampal region, and lowest in the cerebellum. Physostigmine has been found to be eliminated entirely through metabolic pathways and the liver is the most important dispositional pathway for the drug. ${ }^{121}$

In addition to the direct exploitation of natural compounds and their derivatives for drug development, designing novel drugs (drug-like molecules) from natural lead compounds has become more interesting. These drug-like molecules are lower molecular weight substances unlike the hard-core natural derivatives. Moreover, these lead compounds remain an important paradigm in drug discovery, because as they get orally absorbed, they are easily transported to their desired target sites, are not strongly affected by metabolizing enzymes (which form toxic metabolic products), and are easily eliminated from the body without causing adverse side-effects. ${ }^{122}$

\section{Efficacy and safety of botanical AD drugs}

The efficacies of several natural product leads have been evaluated and the leads are under clinical development in hopes of treating AD. Table 2 illustrates the list of some of the plant-derived therapeutic compounds against $\mathrm{AD}$. Among the FDA-approved drugs for the treatment of $\mathrm{AD}$, rivastigmine and galantamine are derived from medicinal plants, which exhibit potential AChE activity. Huperzine A, curcumin, and resveratrol (derived from medicinal plants) also possess excellent anti-Alzheimer activity and they are in Phase III clinical trials.

Several drugs are currently in use for the treatment of AD targeting various pathological events. As mentioned earlier, some of the drugs are in clinical trials and therefore it is necessary to assess the safety aspects of the drug before it is prescribed to patients globally. During the advanced clinical trials, all the adverse effects must be fully documented. Clinical observations need to be supplemented with suitable laboratory tests, and care should be taken regarding the dosage acceptance of the patients, as patients in early stages of AD may experience different effects than patients in advanced stages. Once the drug is administered, special attention should be given to the patients for the observed neurological, psychiatric, and cardiovascular adverse effects both in the long-term and short-term clinical trials. ${ }^{130}$ For

Table 2 List of plant-derived compounds that are FDA-approved and in clinical trials against AD

\begin{tabular}{|c|c|c|c|c|c|c|}
\hline Drugs & Brand name & Plant source & $\begin{array}{l}\text { FDA- } \\
\text { approved }\end{array}$ & $\begin{array}{l}\text { Clinical } \\
\text { trials }\end{array}$ & Targets & Reference \\
\hline Rivastigmine & Exelon & $\begin{array}{l}\text { Physostigma venensosum } \\
\text { Balf. (Leguminosae) }\end{array}$ & 2000 & - & $\begin{array}{l}\text { Inhibits } \mathrm{AChE} \text { in the cortex } \\
\text { and hippocampal region }\end{array}$ & Polinsky ${ }^{123}$ \\
\hline Galantamine & Razadyne & $\begin{array}{l}\text { Lycoris radiata (L'Hér.) } \\
\text { Herb (Amaryllidaceae) } \\
\text { and Galanthus nivalis L. }\end{array}$ & 2001 & - & $\begin{array}{l}\text { Reversible inhibition of } \mathrm{AChE} \\
\text { and allosteric potentiation of } \\
\text { nicotinic } \mathrm{ACh} \text { receptors }\end{array}$ & $\begin{array}{l}\text { Razay and Wilcock; }{ }^{124} \\
\text { Maelicke et al }{ }^{125}\end{array}$ \\
\hline Huperzine A & - & $\begin{array}{l}\text { Huperzia serrata (Thumb) } \\
\text { Trevis (Lycopodiaceae) }\end{array}$ & - & Phase III & $\begin{array}{l}\text { Restores cognitive deficits } \\
\text { by reversibly inhibiting AChE }\end{array}$ & Ha et al ${ }^{126}$ \\
\hline Curcumin & Longvida $^{\circledR}$ & $\begin{array}{l}\text { Curcuma longa L. } \\
\text { (Zingiberaceae) }\end{array}$ & - & Phase II & $\begin{array}{l}\text { Anti-amyloidogenic, anti- } \\
\text { inflammatory, anti-ChE, anti- } \\
\beta \text {-secretase }\end{array}$ & Rajakrishnan et al ${ }^{127}$ \\
\hline Resveratrol & - & Vitis vinifera L. (Vitaceae) & - & Phase III & $\begin{array}{l}\text { Prevents cognitive } \\
\text { impairments and associated } \\
\text { oxidative stress by reducing } \\
\text { plaque formation }\end{array}$ & $\begin{array}{l}\text { Karuppagounder et al; }{ }^{128} \\
\text { Williams et al }\end{array}$ \\
\hline
\end{tabular}

Notes: Exelon (Novartis Pharmaceutical Corporation, East Hanover, NJ, USA); Razadyne (Janssen pharmaceuticals, Inc., Titusville, NJ, USA); Longvida ${ }^{\circledR}$ (Verdure Sciences, Noblesville, IN, USA).

Abbreviations: ACh, acetylcholine; AChE, acetylcholinesterase; AD, Alzheimer's disease; ChE, cholinesterase; FDA, Food and Drug Administration. 
instance, the clinical safety of rivastigmine at its highest dose (6-12 mg/day) was evaluated and the results suggest that the drug did not induce serious problems like hepatic, renal, hematologic, and biochemical changes. However, a small group of patients experienced adverse gastrointestinal effects. ${ }^{131}$ In addition, on behalf of the B303 Exelon study group, Rösler et al ${ }^{132}$ assessed the safety and efficacy of rivastigmine in $\mathrm{AD}$ patients and observed milder effects during dose escalation. Another study led by Yang et $\mathrm{al}^{133}$ demonstrated that during clinical trials, the administration of huperzine A to AD patients had mild adverse events like nausea, anorexia, dizziness, vomiting, constipation, insomnia, excitability, nasal obstruction, diarrhea, and edema. Farlow ${ }^{117}$ suggested that the FDA-approved drug galantamine was well-tolerated in long-term and short-term studies of patients with $\mathrm{AD}$. A 4-week dose escalation of galantamine showed predominantly mild to moderate gastrointestinal problems. Nausea was found to be the most adverse event and it decreased to baseline soon after increasing the dosage. The author also added that AD patients with moderate hepatic impairment need slower dose-escalation schedules than the patients with normal hepatic and renal functions. Similarly, the administration of increased doses of physostigmine also caused adverse effects, which included excessive sweating, salivation, nausea, vomiting, sinus bradycardia, hypotension, muscle weakness, and paralysis. ${ }^{121}$ Therefore, patients are now administered with a varying range of anti-Alzheimer drugs, purely based on the response toward the drugs by the individual.

\section{Acceptability of herbal drugs by AD patients}

Among the various natural-product-derived compounds under clinical trials against $\mathrm{AD}$, huperzine $\mathrm{A}$ has been found to be more specific for $\mathrm{AChE}$ and has prolonged action in the brains of AD patients than the synthetic drug donepezil. ${ }^{134}$ Memantine, which was approved recently, has moderate effects when compared to other drugs, but has better tolerability in AD patients than other drugs. ${ }^{135}$ Phosphatidylserine, derived from lecithin, has been found to protect the neurons in a better way, as it increases the cell membrane integrity and fluidity and also increases the levels of ACh and other neurotransmitters maintaining the balanced levels in $\mathrm{AD}$ patients. ${ }^{136,137}$ The constituents of Gingko biloba leaf extract such as quercitin, kaempferol, and isohamnetin have been found to possess significant antioxidant effects. In addition, G. biloba's neuroprotective effect has been greatly attributed to its anti-inflammatory mechanism by competitively inhibit- ing the platelet activating factor. ${ }^{138}$ Another compound named vinpocetine (derived from Vinca minor L. belonging to the family Apocynaceae), a potent vasodilator, has been found to improve the cognitive effects in $\mathrm{AD}$ patients. ${ }^{139}$ Zhang et al ${ }^{88}$ demonstrated that treatment with curcuminoids (a derivative of a curcumin with different chemical groups) enhances the uptake of $A \beta$ peptide by macrophages by crucially inducing intracellular phagocytosis in an $\mathrm{AD}$ patient's brain. The results also suggest that patients in earlier stages of $\mathrm{AD}$ respond better to the curcuminoid treatment than patients in advanced stages.

\section{Plant-derived and non-plant-derived compounds for $A D$}

The AChE inhibitors were the first approved drugs for the treatment of AD. In 1993 tacrine became the first FDAapproved synthetic drug, which is an AChE inhibitor for the treatment of cognitive loss in AD patients. ${ }^{140}$ Tacrine was found to exhibit reversible noncompetitive inhibition against AChE. However, hepatotoxicity was the most adverse effect that occurred in the patients treated with the drug. ${ }^{141}$ Therefore, the use of tacrine was discontinued in several countries. In 1996, the FDA approved the synthetic drug donepezil, a selective mixed competitive and noncompetitive AChE inhibitor. The predominant adverse effects of donepezil occur in the gastrointestinal tract, resulting in nausea, vomiting, and diarrhea. ${ }^{142}$ Later, several plant-derived AChE inhibitors were approved by the FDA including rivastigmine (2000) and galantamine (2001). Although these plant-derived drugs were also found to exhibit mild to moderate side effects in $\mathrm{AD}$ patients, these effects were decreased to baseline soon after increasing the dosage. ${ }^{124,132}$ In addition to these $\mathrm{ChE}$ inhibitors, cholinergic and nicotinic agonists have been proposed to increase $\mathrm{ACh}$ release in nerve terminals, but they are less effective than the $\mathrm{ChE}$ inhibitors in action. ${ }^{140}$ Memantine, an N-methyl-D-aspartate receptor agonist was approved by the FDA for the treatment of AD in 2004. Memantine exerts its neuroprotective effect by the inhibition of excitotoxicity, which leads to neuronal injury. ${ }^{143}$ A study by Reisberg et al ${ }^{144}$ showed that memantine treated patients showed significantly less deterioration in their functional AD stage. In addition, memantine exerts mild to moderate adverse effects during treatment and the cause of the events was also not attributed directly to the medication. Apart from these plant-derived drugs, certain plant extracts and other secondary metabolites have been found to exhibit neuroprotective effects against AD. Cryptotanshinone (from the roots of $S$. miltiorrhiza Bunge), and L-3-n-Butylphthalide (Apium graveolen L. 
[Apiaceae]) have been found to increase $\alpha$-secretase activity, thereby increasing the production of $\alpha$-secretase-derived soluble amyloid precursor protein alpha fragments. ${ }^{145,146}$ Furanocoumarins isolated from Angelica dahurica (Fisch.) Benth. Et Hooker (Umbelliferae), and protoberberine alkaloids from Coptis chinensis Franch (Ranunculaceae) have been found to inhibit $\beta$-secretase activity, thereby reducing the production of the toxic form of $A \beta$ peptides. ${ }^{147,148}$ In addition to these phytochemicals, several plant-derived compounds with excellent therapeutic potentials like curcumin, resveratrol, and epigallocatechin are still in clinical trials that may benefit AD patients with lesser side effects. ${ }^{113,127-129}$

\section{Challenges in using plant-derived compounds}

There has been a growing interest in alternative therapies, especially in the use of plant-derived natural products. This is due to various facts, including inefficiency of conventional medicines and abusive use of synthetic drugs resulting in side effects. However, certain plants are widely used for various abnormalities and diseases without knowing their toxic effects. Toxicity may result from highly concentrated doses or from the state of conservation of plants and the method of usage. ${ }^{149}$ In addition to the unknown toxic effects, the screening of natural product extract libraries is problematic due to the complex mixtures of predominantly uncharacterized compounds, which can mask the activity of other potential compounds and show false results. Therefore, various sensitive and robust assays have to be employed, which is intricate and complex. ${ }^{150}$

Despite the presence of several compounds in developmental stages, most of the natural-product-derived neurodegenerative compounds still remain on the bench-top, serving as an example of traditional uses of plants. The major problem haunting the development of natural products into clinical pharmaceuticals is the lack of statistically significant clinical efficacy. Most of the reports that are published on neuroprotective effects of natural products are based on in vitro cell-based studies. These in vitro studies should be confirmed in vivo for a complete understanding of the biological activities of these compounds as anti-AD agents. Another important consideration for therapeutic efficacy is bioavailability. ${ }^{151}$ The bioactive compounds should reach the brain in sufficient concentration and should be in the biologically active form to exert their beneficial effects. One of the most of important challenges in developing therapeutic agents from natural products is obtaining the active compounds in large quantities. In addition, compounds that act against a wider range of targets that are associated with the pathology of AD are complicated. Although AChE inhibitors ameliorate the cognitive functions, they neither halt nor delay the disease progression. Hence, the development of single drug that works against crucial targets like $\mathrm{A} \beta$ production, fibrillation, $A \beta$-mediated oxidative stress, and inflammation could be a productive approach to identifying therapeutics against AD. ${ }^{140}$

\section{Conclusion}

To date, there is an insufficiency in understanding the exact pathophysiology of AD and it is a great challenge to find the appropriate treatment for this complex, devastating disease. Natural products have been considered as an important medical reservoir holding enormous potential. Several natural products were found to be effective as a whole molecule or as a lead compound for the treatment of AD. The majority of the compounds with direct relevance to $\mathrm{AD}$ are primarily from plants rather than from microbial sources. The development of plant-based anti-ChE drugs has been considered as a successful effort, which resulted in the advent of novel and potential drugs for the treatment of AD. Moreover, these natural products can be exploited further by chemical derivatization and analog synthesis for a better pharmacokinetic approach and enhanced efficacies. Therefore, natural products have emerged as a promising hope in the field of drug discovery against AD with more emphasis to be made on their safety and clinical aspects.

\section{Disclosure}

The authors report no conflicts of interest in this work.

\section{References}

1. Dastmalchi K, Dorman HJD, Vuorela H, Hiltunen R. Plants as potential sources for drug development against Alzheimer's disease. Intl J Biomed Pharma Sci. 2007;1(2):83-104.

2. Mattson MP. Pathways towards and away from Alzheimer's disease. Nature. 2004;430(7000):631-639.

3. Yoo KY, Park SY. Terpenoids as potential anti-Alzheimer's Disease therapeutics. Molecules. 2012;17(3):3524-3538.

4. Estrada LD, Soto C. Disrupting $\beta$-Amyloid aggregation for Alzheimer Disease treatment. Curr Top Med Chem. 2007;7(1):115-126.

5. Smith MA, Taneda S, Richey PL, et al. Advanced Maillard reaction end products are associated with Alzheimer disease pathology. Proc Natl Acad Sci U SA. 1994;91(12):5710-5714.

6. Sayre LM, Zelasko DA, Harris PL, Perry G, Salomon RG, Smith MA. 4-Hydroxynonenal-derived advanced lipid peroxidation end products are increasedin Alzheimer's disease. J Neurochem. 1997;68(5):2092-2097.

7. Smith CD, Carney JM, Starke-Reed PE, et al. Excess brain protein oxidation and enzyme dysfunction in normal aging and in Alzheimer disease. Proc Natl Acad Sci U S A. 1991;88(23):10540-10543.

8. Perry G, Cash AD, Smith MA. Alzheimer disease and oxidative stress. J Biomed Biotechnol. 2002;2(3):120-123. 
9. Francis PT, Palmer AM, Snape M, Wilcock GK. The cholinergic hypothesis of Alzheimer's disease: a review of progress. J Neurol Neurosurg Psychiatry. 1999;66(2):137-147.

10. Choi BW, Ryu G Park SH, et al. Anticholinesterase activity of plastoquinones from Sargassum sagamianum: Lead compounds for Alzheimer's disease therapy. Phytother Res. 2007;21(5):423-426.

11. Darvesh S, Walsh R, Kumar R, et al. Inhibition of human cholinesterases by drugs used to treat Alzheimer disease. Alzheimer Dis Assoc Disord. 2003;17(2):117-126.

12. Lleó A. Current therapeutic options for Alzheimer's disease. Curr Genomics. 2007;8(8):550-558.

13. Jomova K, Vondrakova D, Lawson M, Valko M. Metals, oxidative stress and neurodegenerative disorders. Mol Cell Biochem. 2010; 345(1-2):91-104.

14. Akiyama H, Barger S, Barnum S, et al. Inflammation and Alzheimer's disease. Neurobiol Aging. 2000;21(3):383-421.

15. Tuppo EE, Arias HR. The role of inflammation in Alzheimer's disease. Int J Biochem Cell Biol. 2005;37(2):289-305.

16. Schott JM, Revesz T. Inflammation in Alzheimer's disease: insights from immunotherapy. Brain. 2013;136(Pt 9):2654-2656.

17. Sheng JG, Mrak RE, Griffin WS. Microglial interleukin-1 expression in brain regions in Alzheimer's disease: correlation with neuritic plaque distribution. Neuropathol Appl Neurobiol. 1995;21(4): 290-301.

18. Mrak RE, Griffin WS. Glia and their cytokines in progression of neurodegeneration. Neurobiol Aging. 2005;26(3):349-354.

19. Eckert A, Keil U, Marques CA, et al. Mitochondrial dysfunction, apoptotic cell death, and Alzheimer's disease. Biochem Pharmacol. 2003;66(8):1627-1634.

20. Paradis E, Douillard H, Koutroumanis M, Goodyer C, LeBlanc A. Amyloid beta peptide of Alzheimer's disease downregulates Bcl-2 and upregulates bax expression in human neurons. J Neurosci. 1996;16(23):7533-7539

21. Dean E. Apoptosis in neurodegeneration: Programmed cell death and its role in Alzheimer's and Huntington's Diseases. Eukaryon 2008;4:42-47.

22. Zlokovic BV. Neurovascular mechanisms of Alzheimer's neurodegeneration. Trends Neurosci. 2005;28(4):202-208.

23. de la Torre JC. Alzheimer's disease is a vasocognopathy: a new term to describe its nature. Neurol Res. 2004;26(5):517-524.

24. Gorelick PB. Risk factors for vascular dementia and Alzheimer's disease. Stroke. 2004;35(11 Suppl 1):2620-2622.

25. Zlokovic BV. Clearing amyloid through the blood-brain barrier J Neurochem. 2004;89(4):807-811.

26. Kawarabayashi T, Younkin LH, Saido TC, Shoji M, Ashe KH, Younkin SG. Age-dependent changes in brain, CSF, and plasma amyloid b protein in the Tg2576 transgenic mouse model of Alzheimer's disease. J Neurosci. 2001;21(2):372-381.

27. Castellano JM, Kim J, Stewart FR, et al. Human apoE isoforms differentially regulate brain amyloid- $\beta$ peptide clearance. Sci Transl Med. 2011;3(89):89ra57.

28. Carmeliet P, De Strooper B. Alzheimer's disease: A breach in the blood-brain barrier. Nature. 2012;485(7399):451-452.

29. Singh AK, Gupta A, Mishra AK, Gupta V, Bansal P, Kumar S. Medicinal plant for curing Alzheimer's Disease. Intl J of Pharm Biol Arch. 2010;1(2):108-114.

30. Perry EK, Pickering AT, Wang WW, Houghton P, Perry NS. Medicinal plants and Alzheimer's disease: Integrating ethnobotanical and contemporary scientific evidence. J Altern Complement Med. 1998;4(4):419-428.

31. Houghton PJ. The role of plants in traditional medicine and current therapy. J Altern Complement Med. 1995;1(2):131-143.

32. Zhao Q, Brett M, Osselaer VN, et al. Galantamine Pharmacokinetics, safety, and tolerability profiles are similar in healthy Caucasian and Japanese subjects. J Clin Pharmacol. 2002;42(9):1002-1010.

33. Atamna H, Frey WH. Mechanisms of mitochondrial dysfunction and energy deficiency in Alzheimer's disease. Mitochondrion. 2007;7(5):297-310.
34. Mancuso C, Scapagnini G, Currò D, et al. Mitochondrial dysfunction, free radical generation and cellular stress response in neurodegenerative disorders. Front Biosci. 2007;12:1107-1123.

35. Bhullar KS, Rupasinghe HPV. Polyphenols: multipotent therapeutic agents in neurodegenerative diseases. Oxid Med Cell Longev. 2013; 2013:1-18.

36. Weinreb O, Mandel S, Amit T, Youdim MB. Neurological mechanisms of green tea polyphenols in Alzheimer's and Parkinson's diseases. J Nutr Biochem. 2004;15(9):506-516.

37. Albarracin SL, Stab B, Casas Z, et al. Effects of natural antioxidants in neurodegenerative disease. Nutr Neurosci. 2012;15(1):1-9.

38. Orhan I, Aslan M. Appraisal of scopolamine-induced antiamnesic effect in mice and in vitro antiacetylcholinesterase and antioxidant activities of some traditionally used Lamiaceae plants. J Ethnopharmacol. 2009; 122(2):327-332.

39. Patel VR, Patel PR, Kajal SS. Antioxidant activity of some selected medicinal plants in western region of India. Adv Biol Res (Rennes). 2010;4(1):23-26.

40. Sultana B, Anwar F, Przybylski R. Antioxidant activity of phenolic components present in barks of Azadirachta indica, Terminalia arjuna, Acacia nilotica, and Eugenia jambolana Lam. trees. Food Chem. 2007;104(3):1106-1114.

41. Souza JNS, Silva EM, Loir A, Rees JF, Rogez H, Larondelle Y. Antioxidant capacity of four polyphenol-rich Amazonian plant extracts: A correlation study using chemical and biological in vitro assays. Food Chem. 2008;106(1):331-339.

42. Amoo SO, Aremu AO, Moyo M, Staden JV. Antioxidant and acetylcholinesterase-inhibitory properties of long-term stored medicinal plants. BMC Complement Altern Med. 2012;12:87.

43. Mokbel MS, Hashinaga F. Evaluation of the antioxidant activity of extracts from buntan (Citrus grandis Osbeck) fruit tissues. Food Chem. 2006;94(4):529-534.

44. Arruda M, Viana H, Rainha N, et al. Anti-acetylcholinesterase and antioxidant activity of essential oils from Hedychium gardnerianum Sheppard ex Ker-Gawl. Molecules. 2012;17(3):3082-3092.

45. Ved HS, Best JM, Dave JR, Doctor BP. Comparative inhibition of acetylcholinesterase by Tacrine, Physostigmine and Huperzine in the adult rat brain, In. Quinn DM, Balasubramanian AS, Doctor BP, Taylor P, editors. Enzymes of the Cholinesterase Family, Part VII. Philadelphia, PA, USA; Springer US. 1995;477-478.

46. Howes MJ, Perry NS, Houghton PJ. Plants with traditional uses and activities relevant to the management of Alzheimer's disease and other cognitive disorders. Phytother Res. 2003;17(1):1-18.

47. Mukherjee PK, Kumar V, Mal M, Houghton PJ. Acetylcholinesterase inhibitors from plants. Phytomedicine. 2007;14(4):289-300.

48. Coulibaly AY, Sombie PAED, Tibiri A, Kiendrebeogo M, Compaore MMY, Nacoulma OG. Protective effect of Scoparia dulcis on brain and erythrocytes. Curr Res J Biol Sci. 2011;3(3):254-261.

49. Miyazawa M, Watanabe H, Kameoka H. Inhibition of acetylcholinesterase activity by monoterpenoids with a p-menthane skeleton. J Agric Food Chem. 1997;45(3):677-679.

50. Ahirwar S, Tembhre M, Gour S, Namdeo A. Anticholinesterase Efficacy of Bacopa monnieri against the Brain Regions of Rat A novel approach to therapy for Alzheimer's disease. Asian J Exp Sci. 2012;26(1):65-70.

51. Grundy DL, Still CC. Inhibition of acetylcholinesterases by pulegone-1, 2-epoxide. Pestic Biochem Physiol. 1985;23(3):383-388.

52. Hou YC, Chao PD, Chen SY. Honokiol and manolol increased hippocampal acetylcholine release in freely moving rats. Am J Chin Med. 2000;28(3-4):379-384.

53. Ferreira A, Proença C, Serralheiro ML, Araújo ME. The in vitro screening for acetylcholinesterase inhibition and antioxidant activity of medicinal plants from Portugal. J Ethnopharmacol. 2006;108(1): 31-37.

54. Wang YE, Yue DX, Tang XC. [Anti-cholinesterase activity of huperzine A]. Zhongguo Yao Li Xue Bao. 1986;7(2):110-113. Chinese. 
55. Ren Y, Houghton P, Hider RC, Howes MJ. Novel diterpenoid acetylcholinesterase inhibitors from Salvia miltiorrhiza. Planta Med. 2004;70(3):201-204.

56. Ghosal S, Bhattacharya SK, Mehta R. Naturally occurring and synthetic $\beta$-Carbolines as cholinesterase inhibitors. J Pharm Sci. 1972;61(5):808-810.

57. Choudhary MI, Nawaz SA, Zaheer-ul-Haq, et al. Juliflorine: a potent natural peripheral anionic-site-binding inhibitor of acetylcholinesterase with calcium-channel blocking potential, a leading candidate for Alzheimer's disease therapy. Biochem Biophys Res Commun. 2005;332(4):1171-1177.

58. Khalid A, Zaheer-ul-Haq, Anjum S, Khan MR, Atta-ur-Rahman, Choudhary MI. Kinetics and structure-activity relationship studies on pregnane-type steroidal alkaloids that inhibit cholinesterases. Bioorg Med Chem. 2004;12(9):1995-2003.

59. Dall'Acqua S. Plant-derived acetylcholinesterase inhibitory alkaloids for the treatment of Alzheimer's disease. Botanics: Targets and Therapy. 2013;3:19-28.

60. Attar-ur-Rahman, Atia-Tul-Wahab, Nawaz SA, Choudhary MI. New cholinesterase inhibiting Bisbenzylisoquinoline alkaloids from Cocculus pendulus. Chem Pharm Bull (Tokyo). 2004;52(7):802-806.

61. Ahmad VU, Khan A, Farooq U, et al. Three new cholinesterase-inhibiting cis-clerodane diterpenoids from Otostegia limbata. Chem Pharm Bull (Tokyo). 2005;53(4):378-381.

62. Lee KY, Yoon JS, Kim ES, Kang SY, Kim YC. Anti-acetylcholinesterase and anti-amnesic activities of a pregnane glycoside, Cynatroside B, from Cynanchum atratum. Planta Med. 2005;71(1):7-11.

63. Khalid A, Azim MK, Parveen S, Atta-ur-Rahman, Choudhary MI. Structural basis of acetylcholinesterase inhibition by triterpenoidal alkaloids. Biochem Biophys Res Commun. 2005;331(4):1528-1532.

64. Andrade MT, Lima JA, Pinto AC, Rezende CM, Carvalho MP, Epifanio RA. Indole alkaloids from Tabernaemontana australis (Müell. Arg) Miers that inhibit acetylcholinesterase enzyme. Bioorg Med Chem. 2005;13(12):4092-4095.

65. Park CH, Kim SH, Choi W, et al. Novel anticholinesterase and antiamnesic activities of dehydroevodiamine, a constituent of Evodia rutaecarpa. Planta Med. 1996;62(5):405-409.

66. Chung YK, Heo HJ, Kim EK, et al. Inhibitory effect of ursolic acid purified from Origanum majorana $\mathrm{L}$ on the acetylcholinesterase. Mol Cells. 2001;11(2):137-143.

67. Orhan I, Terzioglu S, Sener B. Alpha-onocerin: an acetylcholinesterase inhibitor from Lycopodium clavatum. Planta Med. 2003;69(3): 265-267.

68. Heo HJ, Kim MJ, Lee JM, et al. Naringenin from Citrus junos has an inhibitory effect on acetylcholinesterase and a mitigating effect on amnesia dementia. Dement Geriatr Cogn Disord. 2004;17(3): $151-157$.

69. Fujiwara H, Iwasaki K, Furukawa K, et al. Uncaria rhynchophylla, a Chinese medicinal herb, has potent antiaggregation effects on Alzheimer's beta-amyloid proteins. J Neurosci Res. 2006;84(2):427-433.

70. Fujiwara H, Tabuchi M, Yamaguchi T, et al. A traditional medicinal herb Paeonia suffruticosa and its active constituent 1,2,3,4,6-penta-Ogalloyl-beta-D-glucopyranose have potent anti-aggregation effects on Alzheimer's amyloid beta proteins in vitro and in vivo. J Neurochem. 2009;109(6):1648-1657.

71. Papandreou MA, Kanakis CD, Polissiou MG, et al. Inhibitory activity on amyloid-beta aggregation and antioxidant properties of Crocus sativus stigmas extract and its crocin constituents. J Agric Food Chem. 2006;54(23):8762-8768.

72. Durairajan SS, Yuan Q, Xie L, et al. Salvianolic acid B inhibits A $\beta$ fibril formation and disaggregates preformed fibrils and protects against A $\beta$-induced cytotoxicty. Neurochem Int. 2008;52(4-5):741-750.

73. Kang IJ, Jeon YE, Yin XF, et al. Butanol extract of Ecklonia cava prevents production and aggregation of beta-amyloid, and reduces beta-amyloid mediated neuronal death. Food Chem Toxicol. 2011;49(9): 2252-2259.
74. Yang F, Lim GP, Begum AN, et al. Curcumin inhibits formation of amyloid beta oligomers and fibrils, binds plaques, and reduces amyloid in vivo. J Biol Chem. 2005;280(7):5892-5901.

75. Feng Y, Yang SG, Du XT, et al. Ellagic acid promotes Abeta42 fibrillization and inhibits Abeta42-induced neurotoxicity. Biochem Biophys Res Commun. 2009;390(4):1250-1254.

76. Gupta VB, Indi SS, Rao KS. Garlic extract exhibits antiamyloidogenic activity on amyloid- $\beta$ fibrillogenesis: relevance to Alzheimer's disease. Phytother Res. 2009;23(1):111-115.

77. Niidome T, Takahashi K, Goto Y, et al. Mulberry leaf extract prevents amyloid beta-peptide fibril formation and neurotoxicity. Neuroreport. 2007;18(8):813-816

78. Schott JM, Revesz T. Inflammation in Alzheimer's disease: insights from immunotherapy. Brain. 2013;136(Pt 9):2654-2656.

79. Parajuli B, Sonobe Y, Horiuchi H, Takeuchi H, Mizuno T, Suzumura A. Oligomeric amyloid $\beta$ induces IL-1 $\beta$ processing via production of ROS: implication in Alzheimer's disease. Cell Death Dis. 2013;4(12):e975.

80. Breitner JC. The role of anti-inflammatory drugs in the prevention and treatment of Alzheimer's disease. Annu Rev Med. 1996;47:401-411.

81. Breitner JC, Welsh KA, Helms MJ, et al. Delayed onset of Alzheimer's disease with non-steroidal anti-inflammatory and histamine $\mathrm{H} 2$ blocking drugs. Neurobiol Aging. 1995;16(4):523-530.

82. Jenkinson ML, Bliss MR, Brain AT, Scott DL. Rheumatoid arthritis and senile dementia of the Alzheimer's type. Br J Rheumatol. 1989;28(1):86-88.

83. McGeer PL, McGeer E, Rogers J, Sibley J. Anti-inflammatory drugs and Alzheimer disease. Lancet. 1990;335(8696):1037.

84. McGeer PL, Schulzer M, McGeer EG. Arthritis and anti-inflammatory agents as possible protective factors for Alzheimer's disease: a review of 17 epidemiologic studies. Neurology. 1996;47(2):425-432.

85. Howes MJ, Houghton PJ. Plants used in Chinese and Indian traditional medicine for improvement of memory and cognitive function. Pharmacol Biochem Behav. 2003;75(3):513-527.

86. Yu X, Wang LN, Du QM, et al. Akebia Saponin D attenuates amyloid $\beta$-induced cognitive deficits and inflammatory response in rats: involvement of Akt/NF-אB pathway. Behav Brain Res. 2012;235(2): 200-209.

87. Grzanna R, Phan P, Polotsky A, Lindmark L, Frondoza CG. Ginger extract inhibits beta-amyloid peptide-induced cytokine and chemokine expression in cultured THP-1 monocytes. J Altern Complement Med. 2004;10(6):1009-1013.

88. Zhang L, Fiala M, Cashman J, et al. Curcuminoids enhance amyloid- $\beta$ uptake by macrophages of Alzheimer's disease patients. J Alzheimers Dis. 2006;10(1):1-7.

89. Giri RK, Rajagopal V, Kalra VK. Curcumin, the active constituent of turmeric, inhibits amyloid peptide-induced cytochemokine gene expression and CCR5-mediated chemotaxis of THP-1 monocytes by modulating early growth response-1 transcription factor. J Neurochem. 2004;91(5):1199-1210.

90. Pendurthi UR, Rao LV. Suppression of transcription factor Egr-1 by curcumin. Thromb Res. 2000;15;97(4):179-189.

91. Matthew S, Jain AK, James M, Matthew C, Bhowmik D. Analgesic and anti-inflammatory activity of Kalanchoe pinnata (Lam.) Pers. J Med Plants Stud. 2013;1(2):24-28.

92. Kumari STK, Lincy MP, Muthukumarasamy S, Mohan VR. Anti-inflammatory activity of Sarcostemma secamone (1) bennet whole plant against carrageenan induced paw edema. Bioscience Discovery. 2012;3(3):288-291.

93. Leal LK, Ferreira AA, Bezerra GA, Matos FJ, Viana GS. Antinociceptive, anti-inflammatory and bronchodilator activities of Brazilian medicinal plants containing coumarin: a comparative study. J Ethnopharmacol. 2000;70(2):151-159.

94. Zhang L, Ravipati AS, Koyyalamudi SR, et al. Antioxidant and anti-inflammatory activities of selected medicinal plants containing phenolic and flavonoid compounds. J Agric Food Chem. 2011;59(23): 12361-12367. 
95. Sharififar F, Khazaeli P, Alli N, Talebian N, Zarehshahi R, Amiri S. Study of antinociceptive and anti-inflammatory activities of certain Iranian medicinal plants. J Intercult Ethnopharmacol. 2012;1(1):19-24.

96. Kwak HM, Jeon SY, Sohng BH, et al. beta-Secretase (BACE1) inhibitors from pomegranate (Punica granatum) husk. Arch Pharm Res. 2005;28(12):1328-1332.

97. Descamps O, Spilman P, Zhang Q, et al. AßPP-selective BACE inhibitors (ASBI): novel class of therapeutic agents for Alzheimer's Disease. J Alzheimers Dis. 2013;37(2):343-355.

98. Ożarowski M, Mikołajczak PL, BogaczA, Kujawski R, MrozikiewiczPM. Plants and their chemical compounds affecting $\beta$-amyloid and secretase activity as potential sources of neuroprotective herbal medicinal products. Part 1. Herba Polonica. 2010;56(4):91-107.

99. Hwang EM, Ryu YB, Kim HY, et al. BACE1 inhibitory effects of lavandulyl flavanones from Sophora flavescens. Bioorg Med Chem. 2008;16(14):6669-6674.

100. Jeon SY, Kwon SH, Seong YH, et al. $\beta$-secretase (BACE1)-inhibiting stilbenoids from Smilax Rhizoma. Phytomedicine. 2007;14(6): 403-408.

101. Mandel S, Reznichenko L, Amit T, Youdim MB. Green tea polyphenol (-)-epigallocatechin-3-gallate protects rat $\mathrm{PC} 12$ cells from apoptosis induced by serum withdrawal independent of P13-Akt pathway. Neurotox Res. 2003;5(6):419-424.

102. Okello EJ, Savelev SY, Perry EK. In vitro anti- $\beta$-secretase and dual anticholinesterase activities of Camellia sinensis L. (tea) relevant to treatment of dementia. Phytother Res. 2004;18(8):624-627.

103. Kalaria RN. The blood-brain barrier and cerebrovascular pathology in Alzheimer's disease. Ann N Y Acad Sci. 1999;893:113-125.

104. Jiang J, Wang W, Sun YJ, Hu M, Li F, Zhu DY. Neuroprotective effect of curcumin on focal cerebral ischemic rats by preventing blood-brain barrier damage. Eur J Pharmacol. 2007;561(1-3):54-62.

105. Virgili F, Kim D, Packer L. Procyanidins extracted from pine bark protects alpha-tocopherol in ECV 304 endothelial cells challenged by activated RAW 264.7 macrophages: role of nitric oxide and peroxynitrite. FEBS Lett. 1998;431(3):315-318.

106. Zeng LH, Wu J, Fung B, Tong JH, Mickle D, Wu TW. Comparative protection against oxyradicals by three flavonoids on cultured endothelial cells. Biochem Cell Biol. 1997;75(6):717-720.

107. Gerritsen ME, Carley WW, Ranges GE, et al. Flavonoids inhibit cytokine induced endothelial cell adhesion protein gene expression. Am J Pathol. 1995;147(2):278-292.

108. Youdim KA, McDonald J, Kalt W, Joseph JA. Potential role of dietary flavonoids in reducing microvascular endothelium vulnerability to oxidative and inflammatory insults (small star, filled). J Nutr Biochem. 2002;13(5):282-288.

109. Bonoiu A, Mahajan SD, Ye L, et al. MMP-9 gene silencing by a quantum dot-siRNA nanoplex delivery to maintain the integrity of the blood brain barrier. Brain Res. 2009;1282:142-155.

110. Tahanian E, Sanchez LA, Shiao TC, Roy R, Annabi B. Flavonoids targeting of I B phosphorylation abrogates carcinogen-induced MMP-9 and COX-2 expression in human brain endothelial cells. Drug Des Devel Ther. 2011;5:299-309.

111. Hardy J. Amyloid, the presenilins and Alzheimer's disease. Trends Neurosci. 1997;20(4):154-159.

112. Pereira C, Agostinho P, Moreira PI, Cardoso SM, Oliveira CR. Alzheimer's disease-associated neurotoxic mechanisms and neuroprotective strategies. Curr Drug Targets CNS Neurol Disord. 2005;4(4): 383-403.

113. Lee YK, Yuk DY, Lee JW, et al. (-)-Epigallocatechin-3-gallate prevents lipopolysaccharide-induced elevation of beta-amyloid generation and memory deficiency. Brain Res. 2009;1250: 164-174.

114. Findeis MA, Schroeder F, McKee TD, et al. Discovery of a novel pharmacological and structural class of $\gamma$-Secretase modulators derived from the extract of Actaea racemosa. ACS Chem Neurosci. 2012;3(11):941-951.
115. Bolognesi ML, Cavalli A, Valgimigli L, et al. Multi-target-directed drug design strategy: from a dual binding site acetylcholinesterase inhibitor to a trifunctional compound against Alzheimer's disease. J Med Chem. 2007;50(26):6446-6449.

116. Janle EM, Lila MN, Grannan M, et al. Pharmacokinetics and tissue distribution of 14C-labeled grape polyphenols in the periphery and the central nervous system following oral administration. J Med Food. 2010;13(4):926-933.

117. Farlow MR. Clinical pharmacokinetics of galantamine. Clin Pharmacokinet. 2003;42(15):1383-1392.

118. Levin ED, Simon BB. Nicotinic acetylcholine involvement in cognitive function in animals. Psychopharmacology (Berl). 1998;138(3-4): 217-230.

119. Samochocki M, Zerlin M, Jostock R, et al. Galantamine is an allosterically potentiating ligand of the human alpha $4 /$ beta $2 \mathrm{nAChR}$ Acta Neurol Scand Suppl. 2000;176:68-73.

120. Ye JC, Zeng S, Zheng GL, Chen GS. Pharmacokinetics of Huperzine A after transdermal and oral administration in beagle dogs. Int J Pharm. 2008;356(1-2):187-192.

121. Triggle DJ, Mitchell JM, Filler R. The pharmacology of physostigmine. CNS Drug Rev. 1998;4(2):87-136.

122. Ntie-Kang F, Mbah JA, Lifongo LL, et al. Assessing the pharmacokinetic profile of the CamMedNP natural products database: an in silico approach. Org Med Chem Lett. 2013;3(1):10.

123. Polinsky RJ. Clinical pharmacology of rivastigmine: a new-generation acetylcholinesterase inhibitor for the treatment of Alzheimer's disease. Clin Ther. 1998;20(4):634-647.

124. Razay G, Wilcock GK. Galantamine in Alzheimer's disease. Expert Rev Neurother. 2008;8(1):9-17.

125. Maelicke A, Hoeffle-Maas A, Ludwig J, et al. Memogain is a galantamine pro-drug having dramatically reduced adverse effects and enhanced efficacy. $J$ Mol Neurosci. 2010;40(1-2):135-137.

126. Ha GT, Wong RK, Zhang Y. Huperzine a as potential treatment of Alzheimer's disease: an assessment on chemistry, pharmacology, and clinical studies. Chem Biodivers. 2011;8(7):1189-1204.

127. Rajakrishnan V, Viswanathan P, Rajasekharan KN, Menon VP. Neuroprotective role of curcumin from curcuma longa on ethanolinduced brain damage. Phytother Res. 1999;13(7):571-574.

128. Karuppagounder SS, Pinto JT, Xu H, Chen HL, Beal MF, Gibson GE Dietary supplementation with resveratrol reduces plaque pathology in a transgenic model of Alzheimer's disease. Neurochem Int. 2009;54(2):111-118.

129. Williams P, Sorribasa A, Howes MJ. Natural products as a source of Alzheimer's drug leads. Nat Prod Rep. 2011;28(1):48-77.

130. Committee for Medicinal Products for Human Use. Guideline on Medicinal Products for the Treatment of Alzheimer's Disease and other Dementias. London: European Medicines Agency; 2008. Available from: http://www.ema.europa.eu/docs/en_GB/document_library/Scientific_ guideline/2009/09/WC500003562.pdf. Accessed October 12, 2013.

131. Jann MW. Rivastigmine, a new-generation cholinesterase inhibitor for the treatment of Alzheimer's disease. Pharmacotherapy. 2000;20(1):1-12.

132. Rösler M, Anand R, Cicin-Sain A, et al. Efficacy and safety of rivastigmine in patients with Alzheimer's disease: international randomised controlled trial. BMJ. 1999;318(7184):633-638.

133. Yang G, Wang Y, Tian J, Liu JP. Huperzine a for Alzheimer's disease: a systematic review and meta-analysis of randomized clinical trials PLoS One. 2013;8(9):e74916.

134. Wang H, Tang XC. Anticholinesterase effects of huperzine A, E2020, and tacrine in rats. Acta Pharmacologica Sinica. 1998;19(1):27-30.

135. Raina P, Santaguida P, Ismaila A, et al. Effectiveness of cholinesterase inhibitors and memantine for treating dementia: Evidence review for a Clinical practice guideline. Ann. Intern. Med. 2008;148(5):379-397.

136. Crook T, Petrie W, Wells C, Massari DC. Effects of phosphatidylserine in Alzheimer's disease. Psychopharmacol Bull. 1992;28(1): $61-66$. 
137. Zanotti A, Valzelli L, Toffano G. Chronic phosphatidylserine treatment improves spatial memory and passive avoidance in aged rats. Psychopharmacology (Berl). 1989;99(3):316-321.

138. Kudolo GB, Dorsey S, Blodgett J. Effect of the ingestion of Ginkgo biloba extract on platelet aggregation and urinary prostanoid excretion in healthy and Type 2 diabetic subjects. Thromb Res. 2002; 108(2-3):151-160.

139. Valikovics A, Csányi A, Németh L. Study of the effects of vinpocetin on cognitive functions. Ideggyogy Sz. 2012;65(3-4):115-120.

140. Park SY. Potential therapeutic agents against Alzheimer's disease from natural sources. Arch Pharm Res. 2010;33(10):1589-1609.

141. Alfirevic A, Mills T, Carr D, et al. Tacrine-induced liver damage: an analysis of 19 candidate genes. Pharmacogenet Genomics. 2007;17(12):1091-1100.

142. Tsuno N. Donepezil in the treatment of patients with Alzheimer's disease. Expert Rev Neurother. 2009;9(5):591-598.

143. Sonkusare SK, Kaul CL, Ramarao P. Dementia of Alzheimer's disease and other neurodegenerative disorders - memantine, a new hope. Pharmacol Res. 2005;51(1):1-17.

144. Reisberg B, Doody R, Stöffler A, Schmitt F, Ferris S, Möbius HJ. Memantine in moderate-to-severe Alzheimer's Disease. NEngl J Med. 2003;348:1333-1341.

145. Mei Z, Zhang F, Tao L, et al. Cryptotanshinone, a compound from Salvia miltiorrhiza modulates amyloid precursor protein metabolism and attenuates beta-amyloid deposition through upregulating alpha-secretase in vivo and in vitro. Neurosci Lett. 2009;452(2): 90-95.
146. Peng Y, Sun J, Hon S, et al. L-3-n-butylphthalide improves cognitive impairment and reduces amyloid-beta in a transgenic model of Alzheimer's disease. J Neurosci. 2010;30(24):8180-8189.

147. Marumoto S, Miyazawa M. Beta-secretase inhibitory effects of furanocoumarins from the root of Angelica dahurica. Phytother Res. 2010;24(4):510-513.

148. Jung HA, Min BS, Yokozawa T, Lee JH, Kim YS, Choi JS. Anti-Alzheimer and antioxidant activities of Coptidis Rhizoma alkaloids. Biol Pharm Bull. 2009;32(8):1433-1438.

149. Rates SM. Plants as source of drugs. Toxicon. 2001;39(5):603-613.

150. Donnelly AC. Marine Natural Products as Anticancer Agents: Therapeutic Treasures from the Deep. American Chemical Society Division of Organic Chemistry; 2010. Available from: http://www.organicdivision.org/ama/orig/Fellowship/2009_2010_Awardees/Essays/Donnelly. pdf. Accessed January 6, 2014.

151. Rein MJ, Renouf M, Cruz-Hernandez C, Actis-Goretta L, Thakkar SK, da Silva Pinto M. Bioavailability of bioactive food compounds: a challenging journey to bioefficacy. BrJ Clin Pharmacol. 2012;75(3):588-602.
Botanics: Targets and Therapy

\section{Publish your work in this journal}

Botanics: Targets and Therapy is an international, peer-reviewed, open access journal focusing on the discovery and development of active compounds based upon or found naturally occurring in the plant kingdom that may have therapeutic potential in any disease state. The manuscript management system is completely online and includes a very

\section{Dovepress}

quick and fair peer-review system. Visit http://www.dovepress.com/ testimonials.php to read real quotes from published authors. 